\title{
Resources-based Strategies for Health Promotion of Students With Different General Conditions and Different Origins
}

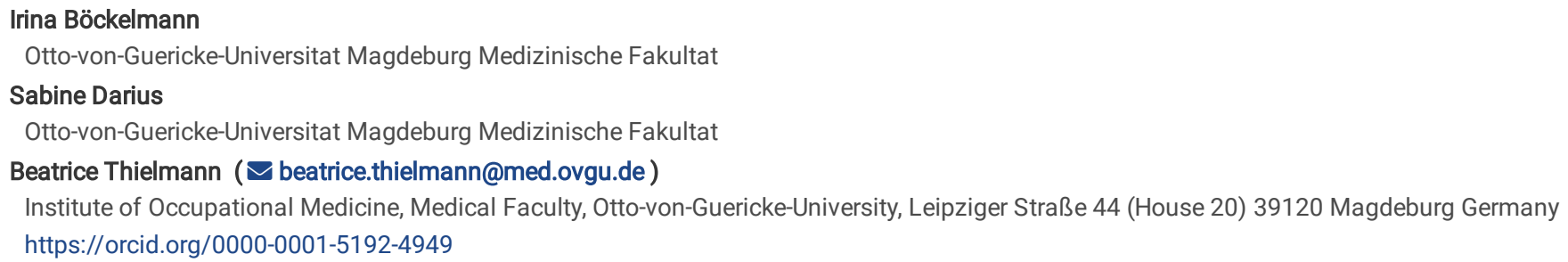

Research article

Keywords: Students, Origins, study-/work-related Behavior and Experience Patterns, resources, prevention, health

Posted Date: September 24th, 2020

DOI: https://doi.org/10.21203/rs.3.rs-71583/v1

License: () (1) This work is licensed under a Creative Commons Attribution 4.0 International License. Read Full License

Version of Record: A version of this preprint was published at Inter Collegas on December 9th, 2021. See the published version at https://doi.org/10.35339/ic.8.3.132-143. 


\section{Abstract}

Background: The aim of this study is to investigate the study-/work-related behavior and experience patterns of students, taking into account their origins as well as the stressful general conditions.

Methods: A total of 194 students (41.8\% women, $58.2 \%$ men, $58.7 \%$ German and $41.3 \%$ foreign students) were evaluated to their strains during the study and study-/work-related Behavior and Experience Patterns (AVEM). Four potentially stressful conditions were taken into account.

Results: For only $14 \%$ of foreign students, but $45 \%$ of German students risk patterns for work-related behavior and experience were found. Study-/work-related behaviour and experience patterns depend on the origin of the students. Resources during study were significantly higher among students of German origin.

Conclusions: A study-related strengthening of resources is necessary, which can be viewed as a competitive advantage when choosing a study location.

\section{Background}

With the implementation of the Bologna Process, there were major changes in the demands and resource profiles of students throughout Europe. The European Higher Education Area (EHEA) and Bologna Process is an international collaboration on higher education of 48 countries, which adapted their higher education systems to making them more compatible and strengthening their quality assurance mechanisms. The aim is to increase staff and students' mobility and to facilitate employability. This is also in the context of increasing globalization and the growing international competition for expertise [1]. These changes also resulted in additional workloads for the students. Half of the students reported that they were regularly under stress, with multiple stressors frequently being present [2]. For $42 \%$ of the students, the strain is caused by a combination of various areas of life. $68 \%$ of whom include their study. In addition, the financial situation (40\%), part-time jobs (40\%), leisure time (39\%), partnerships (32\%), as well as their own health (21\%) and the household (19\%) with children (13\%) also have an impact on the students' reality of life [3, 4]. Mental strain factors as a potential health risk are confronted with numerous resources (organisational, social and personal) as compensation and protection components to avoid or reduce the negative consequences of stressors. Specific personal coping mechanisms across situations and, as a consequence, the management of the stress situation are the conditions for resources to develop their health-protective effect [5].

\section{The mental health of students}

Mental disorders are prevalent among students. According to the WHO (World Health Organization), one fifth of students worldwide had a 12-month DSM-IVbased mental disorder (Diagnostic and Statistical Manual of Mental Disorders), which occurred in 83.1\% of these cases before matriculation. However, only $16 \%$ of students with mental disorders received treatment [6]. Mental disorders have a negative influence on a possible degree and are a new focus of occupational medicine in recent years.

\section{Resources for health promotion}

In the course of coping with the demands, the social environment, an important source of support (e.g. partners, friends, parents, relatives, fellow students), is mainly used [7]. There is an increased requirement for emotional and informal support at the beginning of study[8], and in the progress of the study [9], positive communication leads to better learning outcomes. The third aspect of social support includes instrumental support, where students receive practical and financial support. The most important resources for the health of the students are their own decisions for the place of study, the potential for further qualification or development, the scope for action and the time available for their courses of study [10,11]. New findings show a change from intrinsic to extrinsic motives in the choice of study and point to the new weighting of subsequent fields of employment (71\%) and the inherent potential for development in the job [10]. In addition, living in proximity to the place of residence for keeping up social contacts including family, tutoring programs and the events for first-year students are of great importance. They are a support service in addition to the counselling centers for various problems (stress, university studies with children, legal advice) or the university sports programs for stress reduction (yoga, relaxation methods), they provide central points of contact for every student [12]. A special criteria that has a long-term effect on the health of the students is their study satisfaction. Following the person-job-fit theory [13], an increasing satisfaction is assumed if the discrepancy between the actual and the target value decreases, so that a balanced fit of all areas of life is achieved.

Whether a person can perform the necessary adaptation processes during studies also depends on the personality traits [14]. For example, emotion regulation is needed in examination situations so that fears of performance evaluations are not transformed into thinking blocks. A study showed, that $61 \%$ of the students reported that they can solve their problems by their own coping strategies [15]. Particularly positive values also arise in the self-assessment of healthrelated behavior and the emotional self-concept as aspects of internal resources [2]. The students show a significant optimism and are ready to face the demands of the course. Because a positive correlation between mood and cognitive performance exists, aspects of intrinsic motivation can have particularly promising effects [16]. These are particularly high when students experience themselves in flow while working on a topic. Complete fusion with a task is achieved when a feedback follows on the work done. In order to provide such constructive feedback, a communicative environment in teaching is necessary. If this can be generated, the study program provides a good learning environment for the individual development of stress management and working methods that will enable a future success in the labor market [3]. It is shown that about $40 \%$ ( $32 \%$ women; $52 \%$ men) are physically active at least three times a week and therefore meet WHO requirements [15]. The most important stress management strategy is compensation through sports activities or a particularly healthy lifestyle [2]. 75\% of students would like to follow courses on health promotion. Especially, offers for relaxation and stress management are in high demand among women [17].

A strategy to avoid the long-term consequences of mental strain can only be developed by considering risks and resources together [5]. New models and concepts that explain the relationship between stress and health have resource-oriented approaches to health promotion. These include not only inappropriate strains (stressors) but also resources. 
The aim of the present study is to describe the study-related behavior and experience patterns of students at higher education institutions across different situations and to analyze the available resources, taking into account the students' origins as well as the stressful general conditions. The following questions were examined: Are the manifestations in the various dimensions of work-related behavior and experience patterns (AVEM) of national and foreign students different? What significance does this result then have for the distribution of AVEM patterns in the two groups of students?

\section{Methods \\ Subjects}

A total of 194 students $(41.8 \%$ women $(n=81)$ and $58.2 \%$ men $(n=113))$ from the following faculties were included in the survey: Mechanical Engineering, Humanities, Social Science \& Education, Engineering \& Industrial Design, Medicine, Mathematics, and Social Work, Health \& Media of two universities of a large city in Central Germany, and included network of foreign students from different matriculates and fields of study. The subsample of students with foreign origin comprises 80 participants $(41.2 \%)$ aged between 20 and 30 years $(24.7 \pm 2.4$ years). The subjects of the total sample were on average $23.0 \pm$ 3.4 years old (age range 18-34 years), of which $50 \%$ were younger than 22 years, $25 \%$ between 22 and 25 years and $25 \%$ older than 25 years. The average age of German students was $21.7 \pm 3.5$ years. The home countries of students of foreign origin are widely represented in a total of 36 countries. The gender distribution within both groups of students was not significantly different $(p=0.442)$ : 45 women $(39.5 \%)$ and 69 men $(60.5 \%)$ vs. 36 women $(45.0 \%)$ and 44 men (55.0\%).

\section{Procedure}

The questionnaires were handed out to the participants in paper form and completed independently without any time limit. In the case of language barriers faced by foreign students, they were supported by the research team.

\section{Questionnaire on strains during the study (and at the workplace)}

This questionnaire collects sociodemographic data of the subjects (including age, gender) and information on the study program, the time in hours per week required for the study program, individual protective factors and potentially stressful general conditions such as household, child, care of family members, financing of the study program, possible job opportunities and travel times of the students. This questionnaire asks about burdens in connection with the financing of studies, time burdens during studies and also family burdens.

The following 4 items of the study-related stress factors were used as potentially stressful general conditions: Part-time work/working alongside studying, children, nursing of relatives and travel distance with a journey of more than 120 minutes.

Based on the results on potentially stressful conditions, the students were divided into subgroups with and without stressful conditions: no stressful conditions ( $n S C, n=108,55.7 \%$ ) and with $\geq 1$ stressful conditions (SC, $n=86,44.3 \%$ ). These are later included as covariates in the statistical analysis.

\section{Study-/Work-related Behavior and Experience Patterns (AVEM)}

The questionnaire measures work-related behavior, attitudes and habits [18]. Sixty-six items from the domains of "work commitment", "psychological resilience" and "job-related emotions" are summarized in 11 dimensions obtained by factor analysis as follows: Subjective importance of work in personal life, Work-related ambition, Willingness to work until exhausted, Striving for perfection, Distancing ability (ability to recuperate mentally from work), Tendency to resignation in the face of failure, Proactive problem-solving (active and optimistic attitude), Inner calm and balance (experience of emotional stability), Experience of success at work (satisfaction), Satisfaction with life, Experience of social support. The characteristics of the individual dimensions are shown in Table 1. Stanine values between 4 and 6 are classified as "normal". Depending on their prominence in the particular category, they reflect the four typical workrelated behavior and experience patterns ( $G, S$, risk patterns $A$ and $B)$ [19]. 
Table 1

Expression of the AVEM dimensions within the 4 patterns[18], own presentation

\begin{tabular}{|c|c|c|c|c|}
\hline AVEM & Patte & & & \\
\hline Variables & G & $\mathbf{S}$ & A & B \\
\hline Subjective importance of work in personal life & $\leftrightarrow \uparrow$ & $\downarrow$ & $\uparrow$ & $\downarrow$ \\
\hline Work-related ambition & $\uparrow$ & $\downarrow$ & $\leftrightarrow \uparrow$ & $\downarrow$ \\
\hline Willingness to work until exhausted & $\leftrightarrow$ & $\downarrow$ & $\uparrow$ & $\leftrightarrow$ \\
\hline Striving for perfection & $\leftrightarrow \uparrow$ & $\downarrow$ & $\uparrow$ & $\leftrightarrow \downarrow$ \\
\hline Distancing ability (ability to recuperate mentally from work) & $\leftrightarrow \uparrow$ & $\uparrow$ & $\downarrow$ & $\leftrightarrow \downarrow$ \\
\hline Tendency to resignation in the face of failure & $\downarrow$ & $\leftrightarrow \downarrow$ & $\leftrightarrow \uparrow$ & $\uparrow$ \\
\hline Proactive problem-solving (active and optimistic attitude) & $\uparrow$ & $\leftrightarrow \downarrow$ & $\leftrightarrow \uparrow$ & $\downarrow$ \\
\hline Inner calm and balance (experience of emotional stability). & $\uparrow$ & $\leftrightarrow \uparrow$ & $\downarrow$ & $\downarrow$ \\
\hline Experience of success at work (satisfaction) & $\uparrow$ & $\leftrightarrow \downarrow$ & $\leftrightarrow \uparrow$ & $\downarrow$ \\
\hline Satisfaction with life & $\uparrow$ & $\leftrightarrow \uparrow$ & $\leftrightarrow \downarrow$ & $\downarrow$ \\
\hline Experience of social support & $\leftrightarrow \uparrow$ & $\leftrightarrow$ & $\leftrightarrow \downarrow$ & $\leftrightarrow \downarrow$ \\
\hline
\end{tabular}

Stanine values: $1-3$ under average $\downarrow, 4-6$ average $\leftrightarrow$ (tendency to 4 additionally with $\downarrow$ and tendency rather to 6 additionally with $\uparrow$ ), 7-9 above average $\uparrow$. Health-promoting patterns $\mathrm{G}$ and S. Risk patterns $\mathrm{A}$ and $\mathrm{B}$.

\section{Statistical methods:}

All analyses were performed in SPSS Statistics 26 for windows. It was tested for normal distribution using the Kolmogorov-Smirnov test. The Chi-square test was used to test the distribution of subgroups of different origin and subgroups with and without stressful conditions. The Fishers Exact Test was used to compare the distribution of the different frequency occurrence of different resources and the distribution of AVEM patterns in the subgroups of students of German and foreign origin. The Mann-Whitney U-test was used to assess the impact of low-value resources and the impact of the AVEM categories. In addition, the General Linear Model (GLM), test for intermediate subjects, corrected model) was applied, taking into account the general conditions. A Bonferroni test was performed. The significance level was based on a $5 \%$ significance level.

\section{Results}

\section{General information about the students and conditions}

More than half of the students have no stressful general condition, $38.7 \%$ have one, and $5.7 \%$ of the students have at least two or more general conditions (Fig. 1). Of the 57 students of German origin with stressful conditions, 46 had only one, 10 had two and 1 had three or more stressful general conditions. Of 29 students from foreign countries with stressful conditions, all of them stated that they only had one potentially stressful condition. The allocation of the origin of the respondents with and without stressful conditions in the student groups did not differ significantly $(p=0.058)$. The age of respondents in these two subgroups with different conditions was also similar ( $22.5 \pm 3.1$ years for participants in group nSC, $23.5 \pm 3.7$ years for those in group SC).

The average distance to the university is between $8.2 \pm 15.67 \mathrm{~km}$ (range 0.5 and $120 \mathrm{~km}$ ) and the drive takes between 3 and 120 minutes. The time required for studying (lectures, seminars and practical training) was up to 45 hours per week ( $\varnothing 19.2 \pm 9.4$ hours per week). Taking into account the preparation and followup time, this was as much as 56 hours per week ( $\varnothing 15.6 \pm 10.9$ hours per week). The time invested in household activities during the semester and holidays is roughly comparable ( $6.1 \pm 4.3$ hours versus. $6.5 \pm 5.0$ hours). The students had an average employment of $5.6 \pm 10.64$ (range $0-80$ ) hours per week during the semester and $12.8 \pm 17.49$ (range $0-120$ ) hours per week during the semester break. 6 students of German origin (3.1\% of the total sample) have children. All students from foreign countries are childless. The average percentage of financing for studies by parents was $57.9 \pm 40.2 \%$ in the overall sample (German versus foreign origins $58.5 \% / 41.5 \%$ ). Other financing options were available to $13.8 \pm 2.7 \%$ of the students through the BAföG scholarship (state support for the training of pupils and students in Germany), $17.4 \pm 28.5 \%$ through their own income, $5.6 \pm 20.0 \%$ through other scholarships and $4.4 \pm 16.2 \%$ through other income. In the case of 27 German students (23.9\%) and 39 foreign students (48.8\%), $100 \%$ of the financing for their studies was provided by their parents. Only 6 students from Germany financed $100 \%$ of their study with the BAföG scholarship, for all others the BAföG scholarship is only a part of the financing of their studies. Another 6 students (7.5\%) financed their studies with other scholarships. $1.8 \%$ of students of German origin $(n=2)$ and $7.5 \%(n=6)$ of foreign students financed their studies $100 \%$ from their own income.

\section{Resources of the students}

In the survey on resources during study, it was found that the enjoyment of studying and part-time work as well as the collegial and open atmosphere in the environment was subjectively significantly higher among students of German origin (Table 2). They also felt more support for professional interests from their immediate circle. 
Table 2

Presence of different resources in the total sample and the subgroups of students

\begin{tabular}{|c|c|c|c|c|}
\hline \multirow[t]{2}{*}{ Resources } & Total & Germany & Foreign countries & \multirow[t]{2}{*}{ P Pishers exakt test } \\
\hline & \multicolumn{3}{|c|}{ incidence [\%] } & \\
\hline \multicolumn{5}{|c|}{ Enjoyment of study and work } \\
\hline never & 1.6 & 0.9 & 2.5 & \multirow[t]{4}{*}{$<0.001$} \\
\hline rarely & 10.9 & 4.5 & 20.0 & \\
\hline sometimes & 41.1 & 35.7 & 48.8 & \\
\hline often & 46.4 & 58.9 & 28.7 & \\
\hline \multicolumn{5}{|c|}{ Collegial and welcoming atmosphere in the environment } \\
\hline never & 2.1 & 0 & 5.0 & \multirow[t]{4}{*}{0.001} \\
\hline rarely & 9.4 & 6.3 & 13.8 & \\
\hline sometimes & 37.0 & 31.3 & 45.0 & \\
\hline often & 51.6 & 62.5 & 36.3 & \\
\hline \multicolumn{5}{|c|}{ Support of family/partner in their professional interests } \\
\hline never & 4.7 & 3.5 & 6.3 & \multirow[t]{4}{*}{0.002} \\
\hline rarely & 9.3 & 6.2 & 13.8 & \\
\hline sometimes & 28.5 & 21.2 & 38.8 & \\
\hline often & 57.5 & 69.0 & 41.2 & \\
\hline
\end{tabular}

Table 3 shows the impact of scantly available or pronounced resources. In most cases, students do not feel stressed. Foreign students felt more stressed by a less welcoming and collegial atmosphere or a lack of support, but no significant statistical differences between German and foreign students were found. Students from other countries feel more stressed if these three stress factors were more pronounced for them and the general conditions were taken into account.

Table 3: Expression of strain caused by low available resources in the total sample and in the subgroups of students

\begin{tabular}{|c|c|c|c|c|c|c|c|}
\hline \multirow[t]{4}{*}{ Resources } & \multirow[t]{2}{*}{ Total } & \multirow[t]{2}{*}{ Germany } & \multirow[t]{2}{*}{$\begin{array}{l}\text { Foreign } \\
\text { countries }\end{array}$} & \multirow[t]{4}{*}{$\begin{array}{l}\text { PMann- } \\
\text { Whitney-U }\end{array}$} & \multicolumn{3}{|c|}{$\begin{array}{l}\text { GLM with general conditions as } \\
\text { covariate }\end{array}$} \\
\hline & & & & & $\mathrm{F}$ & $\mathrm{p}$ & $\mathrm{p}_{\text {Bonferroni }}$ \\
\hline & \multicolumn{6}{|l|}{$\mathrm{AV} \pm \mathrm{SD}$} & \\
\hline & \multicolumn{6}{|c|}{ Median (min-max) } & \\
\hline \multirow[t]{2}{*}{ Enjoyment of study and work } & $0.53 \pm$ & $0.41 \pm$ & \multirow{2}{*}{$\begin{array}{l}0.69 \pm 1.001 \\
0(0-3)\end{array}$} & \multirow[t]{2}{*}{0.080} & \multirow[t]{2}{*}{2.352} & \multirow[t]{2}{*}{0.098} & \multirow[t]{2}{*}{0.031} \\
\hline & $0(0-3)$ & $0(0-3)$ & & & & & \\
\hline \multirow[t]{2}{*}{$\begin{array}{l}\text { Collegial and welcoming atmosphere in the } \\
\text { environment }\end{array}$} & $\begin{array}{l}0.39 \pm \\
0.770\end{array}$ & $\begin{array}{l}0.29 \pm \\
0.642\end{array}$ & \multirow{2}{*}{$\begin{array}{l}0.51 \pm 0.900 \\
0(0-3)\end{array}$} & \multirow[t]{2}{*}{0.081} & \multirow[t]{2}{*}{1.908} & \multirow[t]{2}{*}{0.151} & \multirow[t]{2}{*}{0.055} \\
\hline & $0(0-3)$ & $0(0-3)$ & & & & & \\
\hline \multirow{2}{*}{$\begin{array}{l}\text { Support of family/partner in their professional } \\
\text { interests }\end{array}$} & $0.38 \pm$ & $0.29 \pm$ & \multirow{2}{*}{$\begin{array}{l}0.53 \pm 0.941 \\
0(0-3)\end{array}$} & \multirow[t]{2}{*}{0.128} & \multirow[t]{2}{*}{2.294} & \multirow[t]{2}{*}{0.104} & \multirow[t]{2}{*}{0.035} \\
\hline & $0(0-3)$ & $0(0-3)$ & & & & & \\
\hline
\end{tabular}

\section{Study-/Work-related Behavior and Experience Patterns (AVEM) of the students}

Table 4 shows the stanine values of the total sample for the 11 categories of the AVEM. The Work-related ambition of the total sample reached the highest score of $6.1 \pm 1.6$ points; with an average value of $6.4 \pm 1.6$ points, the students of German origin were higher compared to norm values. The lowest values, which were also under the norm, were found in the categories of Proactive problem-solving ( $3.9 \pm 1.7$ points) and the Experience of success at work (satisfaction) ( $3.5 \pm 2.00$ points). Particularly low values were found in the group of foreign origin. In addition, the stanine values of the categories Satisfaction with life and Experience of social support among foreign students were below the normal range and differed significantly from the values of students of 
German origin $(p<0.001)$. Only in the AVEM category Tendency to resignation in the face of failure are the groups of different origin comparable. These differences in the AVEM categories among students of different origins are maintained if the general conditions are included as covariates in the statistical analysis and the Bonferroni correction. Also here, only in the category of resignation tendency, no significant differences between the groups can be demonstrated Tendency to resignation in the face of failure. Most categories of the work/study-related behavior and experience patterns depend on the origin of the person during their studies. Only the categories Subjective importance of work in personal life and Willingness to work until exhausted were less prominent among students of German origin than among their fellow students $(p<0.001$ and $p=0.005)$. This questionnaire also shows significantly lower levels of subjectively evaluated Satisfaction with life and experience of social support among foreign students.

Table 4: Expression of the AVEM categories (stanine values) in the total sample and the subgroups of students

\begin{tabular}{|c|c|c|c|c|c|c|c|}
\hline \multirow[t]{3}{*}{ AVEM category } & \multirow{2}{*}{$\begin{array}{l}\text { Total } \\
\mathrm{AV} \pm \mathrm{SD}\end{array}$} & \multirow[t]{2}{*}{ Germany } & \multirow[t]{2}{*}{$\begin{array}{l}\text { Foreign } \\
\text { countries }\end{array}$} & \multirow[t]{3}{*}{$\begin{array}{l}\text { PMann- } \\
\text { Whitney-U }\end{array}$} & \multicolumn{3}{|c|}{$\begin{array}{l}\text { GLM with general conditions as } \\
\text { covariate }\end{array}$} \\
\hline & & & & & $F$ & $\mathbf{p}$ & PBonferroni \\
\hline & \multicolumn{6}{|c|}{ Median (min-max) } & \\
\hline \multirow[t]{2}{*}{ Subjective importance of work in personal life } & $4.9 \pm$ & $4.4 \pm$ & \multirow{2}{*}{$\begin{array}{l}5.6 \pm 1.49 \\
5.5(1-8)\end{array}$} & \multirow[t]{2}{*}{$<0.001$} & \multirow[t]{2}{*}{11.558} & \multirow[t]{2}{*}{$<0.001$} & \multirow[t]{2}{*}{$<0.001$} \\
\hline & $\begin{array}{l}5(1- \\
9)\end{array}$ & & & & & & \\
\hline \multirow[t]{2}{*}{ Work-related ambition } & $\begin{array}{l}6.1 \pm \\
1.65\end{array}$ & $\begin{array}{l}6.4 \pm \\
1.65\end{array}$ & \multirow{2}{*}{$\begin{array}{l}5.8 \pm 1.61 \\
6(1-9)\end{array}$} & \multirow[t]{2}{*}{0.019} & \multirow[t]{2}{*}{2.793} & \multirow[t]{2}{*}{0.064} & \multirow[t]{2}{*}{0.019} \\
\hline & $\begin{array}{l}6(1- \\
9)\end{array}$ & $6(3-9)$ & & & & & \\
\hline \multirow[t]{2}{*}{ Willingness to work until exhausted } & $\begin{array}{l}4.6 \pm \\
1.81\end{array}$ & $\begin{array}{l}4.3 \pm \\
1.87\end{array}$ & \multirow{2}{*}{$\begin{array}{l}5.1 \pm 1.66 \\
5(1-9)\end{array}$} & \multirow[t]{2}{*}{0.004} & \multirow[t]{2}{*}{4.385} & \multirow[t]{2}{*}{0.014} & \multirow[t]{2}{*}{0.005} \\
\hline & $\begin{array}{l}5(1- \\
9)\end{array}$ & $4(1-9)$ & & & & & \\
\hline \multirow[t]{2}{*}{ Striving for perfection } & $\begin{array}{l}4.6 \pm \\
1.85\end{array}$ & $\begin{array}{l}5.0 \pm \\
1.93\end{array}$ & \multirow{2}{*}{$\begin{array}{l}4.1 \pm 1.63 \\
4(2-9)\end{array}$} & \multirow[t]{2}{*}{0.001} & \multirow[t]{2}{*}{5.419} & \multirow[t]{2}{*}{0.005} & \multirow[t]{2}{*}{0.002} \\
\hline & $\begin{array}{l}4(1- \\
9)\end{array}$ & $5(1-9)$ & & & & & \\
\hline \multirow[t]{2}{*}{$\begin{array}{l}\text { Distancing ability (ability to recuperate mentally } \\
\text { from work) }\end{array}$} & $\begin{array}{l}5.6 \pm \\
1.53\end{array}$ & $\begin{array}{l}5.9 \pm \\
1.61\end{array}$ & \multirow{2}{*}{$\begin{array}{l}5.3 \pm 1.34 \\
5(2-9)\end{array}$} & 0.019 & 3.59 & 0.023 & 0.007 \\
\hline & $\begin{array}{l}5(2- \\
9)\end{array}$ & $6(3-9)$ & & & & & \\
\hline Tendency to resignation in the face of failure & $\begin{array}{l}5.4 \pm \\
1.68\end{array}$ & $\begin{array}{l}5.3 \pm \\
1.90\end{array}$ & $5.5 \pm 1.33$ & 0.777 & 0.265 & 0.768 & 0.679 \\
\hline & $\begin{array}{l}5(1- \\
9)\end{array}$ & $5(1-9)$ & $6(2-9)$ & & & & \\
\hline $\begin{array}{l}\text { Proactive problem-solving (active and optimistic } \\
\text { attitude) }\end{array}$ & $\begin{array}{l}3.9 \pm \\
1.72\end{array}$ & $\begin{array}{l}4.2 \pm \\
1.72\end{array}$ & $3.4 \pm 1.64$ & 0.003 & 6.881 & 0.001 & 0.011 \\
\hline & $\begin{array}{l}4(1- \\
9)\end{array}$ & $4(1-9)$ & $3(1-9)$ & & & & \\
\hline $\begin{array}{l}\text { Inner calm and balance (experience of emotional } \\
\text { stability). }\end{array}$ & $\begin{array}{l}4.9 \pm \\
1.62\end{array}$ & $\begin{array}{l}5.1 \pm \\
1.85\end{array}$ & $4.6 \pm 1.22$ & 0.049 & 2.631 & 0.075 & 0.044 \\
\hline & $\begin{array}{l}5(1- \\
9)\end{array}$ & $5(1-9)$ & $5(2-9)$ & & & & \\
\hline Experience of success at work (satisfaction) & $\begin{array}{l}3.5 \pm \\
1.99\end{array}$ & $\begin{array}{l}3.8 \pm \\
2.17\end{array}$ & $3.0 \pm 1.62$ & 0.015 & 4.962 & 0.008 & 0.015 \\
\hline & $\begin{array}{l}3(1- \\
9)\end{array}$ & $3(1-9)$ & $3(1-8)$ & & & & \\
\hline Satisfaction with life & $\begin{array}{l}4.2 \pm \\
1.78\end{array}$ & $\begin{array}{l}4.7 \pm \\
1.88\end{array}$ & $3.4 \pm 1.31$ & $<0.001$ & 17.629 & $<0.001$ & $<0.001$ \\
\hline & $\begin{array}{l}4(1- \\
9)\end{array}$ & $5(1-9)$ & $3(1-7)$ & & & & \\
\hline Experience of social support & $\begin{array}{l}4.8 \pm \\
2.14\end{array}$ & $5.6 \pm$ & $3.6 \pm 1.90$ & $<0.001$ & 25.277 & $<0.001$ & $<0.001$ \\
\hline & $\begin{array}{l}5(1- \\
9)\end{array}$ & $5(1-9)$ & $3(1-9)$ & & & & \\
\hline
\end{tabular}


Students were classified into the four work-related behavior and experience patterns (AVEM patterns) based on the characteristics of the AVEM categories (Fig. 2). Among students of German origin, $45 \%(n=36)$ exhibited risk patterns $A(20 \%)$ or $B(25 \%)$. The others in this subgroup were assigned to pattern $G(n=$ $24 ; 30 \%)$ and pattern $S(n=20 ; 25 \%), 34$ of the respondents could not be classified into the 4 AVEM patterns. This distribution was significantly different ( $p<$ 0.001 ) in the subgroups of students of German and foreign origin. Only $14 \%$ of students from foreign countries had risk patterns A (10.5\%) or B (3.5\%). A significantly larger proportion of students of foreign origin (86\%) had the health-promoting patterns G (31.6\%) or S (54.4\%).

Further examination of these AVEM patterns shows no significant difference $(p=0.811)$ in the allocation of subgroups with and without potentially stressful conditions. In the group of students with pattern A and in the group with pattern $\mathrm{G}$, half of the respondents stated that they had stressful conditions. The other half had no stressful conditions. In pattern B, this distribution is slightly different: $45.5 \%$ with vs. $54.5 \%$ without stressful conditions. In the case of the pattern S, $56.9 \%$ of the test persons did not have any stressful conditions and $43.1 \%$ indicated one or more stressful conditions.

\section{Discussion}

This study examines study-/work-related behavior and experience patterns and resources of students in comparison of German and foreign origin, taking into account potentially stressful conditions. There are significant differences between the groups. This work presents a theoretical background rather than a phenomenological description and shows that students also need help and support at the beginning of their professional careers. Interestingly, in our sample, only $14 \%$ of foreign students, but $45 \%$ of German students were found to have risk patterns for work-related behavior and experience. There are differences in the study-/work-related behavior and experience patterns depending on the origin of the students. Satisfaction with life and Experience of social support was significantly lower and even under the norm among foreign students compared to their German colleagues. In contrast, the Willingness to work until exhausted was higher among foreign students than among German students, which seems unfavorable. A "no failure" in front of the family seems to be a reason here or the chance to get a job in Germany. All categories, with the exception of the Tendency to resignation in the face of failure, showed significant differences, with the foreign group scoring less favorably. A study of teaching students also indicates a problematic stress level among students. For more than $40 \%$ of the respondents, an AVEM risk pattern (A or B) with less favorable values in General Health Questionnaire 12 has been found [20]. The results show the importance of health promotion and prevention programs for students, even in a university setting. Unfortunately, only about $50 \%$ of all German universities offer health promotion and prevention [21]. Data from the German Student Union show that the need for consultation on study-related, performance-related, financial and personal problems has risen to $61 \%$ [22]. At $13 \%$ of the consultations are on the basis of a burnout-associated depressive disorder. Primary prevention in the context of psychotherapeutic student counselling (PSB) at the university location record an increase of $261 \%$ in the number of clients and a simultaneous decrease by $12 \%$ in the number of courses [23]. In 2018, 410 students used the services of the PSB, which at $15.9 \%$ is the highest level since data collection[24]. The students seeking counselling are most frequently affected by the impairment of their ability to study. In particular, $57.7 \%$ are affected by learning and work problems (including performance problems, difficulties in work organization or time management) and $54.8 \%$ by examination or failure fears[24]. A self-assessment showed that $14 \%$ of the students considered themselves to be at risk of burnout; according to the consultants' assessment, the figure was as high as $21 \%$ [24]. It is alarming that $75.5 \%$ of the students seeking counselling suffered from one or more physical or psychosomatic complaints such as headaches or backaches, gastrointestinal problems or sleep disorders [24]. Nearly half of the students showed a small increase in their health status as a result of the PSB. The students developed an understanding of their problem situation, including the realization that further treatment is necessary. The PSB has often initiated conciliation, which confirms the usefulness of such consultations[23, 24].

In addition to counselling, the implementation of a study-related stress management course appears to be useful. A survey of work-related behavior and experience patterns among students found AVEM risk patterns in $88.9 \%$ of students before starting a stress management course, which was implemented over 8 weeks during the semester. It could be shown that health-promoting AVEM patterns increased in the course of the treatment and remained stable for 3 months even after independent application [25]. In a survey of German teachers and in contrast to this survey, the health-promoting patterns $\mathrm{G}$ and $\mathrm{S}$ were represented in the majority. Only one third of the teachers had AVEM risk patterns A and B [26]. Compared to other disciplines, student teachers generally show a predominance of health-promoting patterns.

Besides the courses on stress management, there is also the student project "Nightline", which is specifically designed to meet the needs of students with families. It offers childcare options even during the summer holidays and annual family scholarships. In addition, social counselling, law advice, office hours of the health insurance companies in the Campus Service Center of the universities, the company relay races or health days and campaigns (Heart Health Project Week 2018, Bicycle Action Day 2017, Back Check 2012) are central offers for all those involved in the university institutions. However, typical measures in the context of occupational health management (e.g. massage, health-related education and training, discounts in health centers) are not available to students. Financial support for students at higher education institutions can be provided through regular scholarships (Germany scholarship, company scholarship, family scholarship) to promote particularly engaged students. A flexibilization and free scheduling of the attended modules increases the selfefficacy expectations of the students [11, 27]. Significant positive correlation was shown between social support and mental health [28]. The course of data collection shows that the number of students of foreign origin looking for counseling has increased from $13.8 \%$ in 2017 to $16.6 \%$ in 2018 . This increase in our clientele developed equivalently to the proportion of international students at the universities (from 15.9\% in 2015 to 21.7\% in 2018) [24]. It seems quite important to pay attention to the origin of the students. One study showed that with similar levels of stress during studies, an increased suicidal tendency was observed among Chinese students compared to American students [29]. This could indicate, among other things, fear of failure in the family.

As a limitation, it should be noted that the period of the survey was not recorded reliably. It cannot be surely clarified whether strains on students during their studies or the general conditions are a greater strain factor. Surveys at the end of the semester can cause higher demands than at the beginning because the general conditions have already been passed for several weeks and especially at the end of the semester there are also exams. In the case of questionnaires on paper, answers in the sense of social wishful thinking are possible. If there are language barriers for foreign students, uncertainties in the answers are possible despite the presence of an interpreter.

\section{Conclusions}


In summary, it should be commented that a study-related strengthening of resources is necessary, which can definitely be viewed as a competitive advantage to be chosen as a study location. The identified framework conditions, the origin and resources of the students play a role in study- or work-related behavior and experience patterns. This should be taken into account in health promotion programs and, most importantly, not only minimize strains but also "work out" resource-oriented strategies. Improving organizational factors (e.g. information flow, exam scheduling, theoretical and practical teaching quality, time and performance pressure, social interactions and individual characteristics (e.g. self-expectation, fear of failure) has been shown to reduce stress [30]. These organizational factors could correspond to our recorded resources such as enjoyment of study and work or collegial and welcoming atmosphere in the environment. A strengthening of resources could also be achieved through newer procedures such as "Telemental Health". This would reduce barriers in the search for psychosocial help and support students who are searching for advice [31].

\section{Abbreviations}

AVEM Study-/work-related behavior and experience patterns

\section{A, B, G, S AVEM pattern}

DSM-IV Diagnostic and Statistical Manual of Mental Disorders

EHEA European Higher Education Area

GLM General Linear Model

nSC no stressful conditions

PSB Psychotherapeutic student counselling

SC stressful conditions

WHO World Health Organization

\section{Declarations}

Ethics approval and consent to participate

The Otto von Guericke University in Magdeburg, Germany (register no. 65/08) gave positive ethical opinions. The study complied with the guidelines of Declaration of Helsinki. The consent of the study participants was given in writing.

Consent for publication

All authors give their consent to publication.

Funding Sources

There are no sources of financing.

Competing Interests

The authors declare that there is no conflict of interest.

Availability of data and material (data transparency)

The data can be requested from the authors.

Authors' contributions

IB is the first author of the publication and responsible for data collection.SD and BT have applied statistical methods in data evaluation. SD and BT also coauthored the manuscript. All authors have read and approved the manuscript

Acknowledgements

We would like to thank Jessica Linke, Shawki Bahmad and Claudia Schupp, who were particularly involved in the initial phase of the study.

\section{References}

1. Fang J, Zhai J. Abdulrahman Al-Youbi A, Zahed W Tierney, editor: Successful global collaborations in higher education institutions. Higher Education. 2020;80:597-9. doi:10.1007/s10734-019-00493-2.

2. Kirsch A-S, Laemmert P, Tittlbach S. Health demands and resources of students. A study with students of Sports, Business and Law. Prävention und Gesundheitsförderung. 2017;12:181-8. doi:10.1007/s11553-017-0584-3.

3. Schäfer A. Mental stress during studies: data, facts, fields of action - an overview. Kunstakademie Düsseldorf; 7./8. Oktober 2013.

Page 8/10 
4. Braun M, Laging M, Heidenreich T, Ganz T. Health reporting at Esslingen University of Applied Sciences using the example of the study "Living and processing stress among students. Gesundheitswesen. 2014;76:A15. doi:10.1055/s-0034-1386865.

5. Böckelmann I, Seibt R. Methods for the indication of predominant mental workload and strain at work - possibilities for the corporate practice. Zeitschrift für Arbeitswissenschaft. 2011;65:205-22. doi:10.1007/BF03373839.

6. Auerbach RP, Alonso J, Axinn WG, Cuijpers P, Ebert DD, Green JG, et al. Mental disorders among college students in the World Health Organization World Mental Health Surveys. Psychol Med. 2016;46:2955-70. doi:10.1017/S0033291716001665.

7. Lörz M, Schindler S. Gender differences in the transfer to higher education. In: Hadjar A, editor. Gender-specific educational inequalities. Wiesbaden: VS Verlag für Sozialwissenschaften; 2011.

8. Faller G, Schnabel EP, editors. Ways to a healthy university: A practical guide. 1st ed. Berlin: Edition Sigma; 2006.

9. Kek B, Buchanan J, Adisesh A. An Introduction to Occupational Medicine Using a Team-Based Learning Methodology. Journal of Occupational and Environmental Medicine. 2019;61.

10. Herrmann A. Continuing education courses in Germany's tertiary education system after the Bologna reform [Dissertation]. Jena: Friedrich-SchillerUniversität; 2017.

11. Grützmacher J, Gusy B, Lesener T, Sudheimer S, Willige J. Health of Students in Germany 2017. A cooperative project between the German Center for Higher Education and Science Research, Freie Universität Berlin, and Techniker Krankenkasse. 2018. https://www.ewi-psy.fu-

berlin.de/einrichtungen/arbeitsbereiche/ppg/bwb-2017/_inhaltselemente/faktenblaetter/ Gesamtbericht-Gesundheit-Studierender-in-Deutschland2017.pdf. Accessed 17 Jul 2020.

12. Herbst U, Voeth M, Eidhoff AT, Müller M, Stief S. Student stress in Germany - an empirical study. Berlin: AOK-Bundesverband; 2013.

13. Weinert AB. Organizational psychology: a textbook. Weinheim: Beltz/Psychologie Verlags Union; 1998.

14. Fabianek M. Which attributes influence the success of the studies? [Diploma]. Erlangen-Nürnberg: Friedrich-Alexander-Universität; 2004.

15. Stock C. How important is health for the academic achievement of students? Prävention und Gesundheitsförderung. 2017;12:230-3. doi:10.1007/s11553-017-0609-y.

16. Faller G. Health at university: conditions and resources. In: Faller G, Schnabel EP, editors. Ways to a healthy university: A practical guide. 1st ed. Berlin: Edition Sigma; 2006. pp. 49-57.

17. Tervooren N. Compensation and coping with stress of students [Master thesis]. Neubrandenburg: Hochschule Neubrandenburg; 2016.

18. Schaarschmidt U, Fischer AW. Work-related behaviour and experience patterns. Test instructions. Mödling: Dr.G.Schuhfried GmbH; 2004.

19. Schaarschmidt U. AVEM - A personality diagnostic tool for occupational rehabilitation. In: Arbeitskreis Klinische Psychologie in der Rehabilitation BDP, editor. Diagnostik - Weichenstellung für den Reha-Verlauf. Bonn: Deutscher Psychologen Verlag GmbH; 2006. pp. 59-82.

20. Zimmermann L, Unterbrink T, Pfeifer R, Wirsching M, Rose U, Stößel U, et al. Mental health and patterns of work-related coping behaviour in a German sample of student teachers: a cross-sectional study. Int Arch Occup Environ Health. 2012;85:865-76. doi:10.1007/s00420-011-0731-7.

21. Michel S, Sonntag U, Hungerland E, Nasched M, Schluck S, Sado F. Bergmüller A. Health promotion at German universities: Results of an empirical study. Grafling: Verlag für Gesundheitsförderung.; 2018.

22. Gusy B, Lohmann K, Marcus K. Are bachelor/master students more burned out? Prävention und Gesundheitsförderung. 2012;7:237-45. doi:10.1007/s11553-012-0358-x.

23. Ackermann E. Primärprävention im Rahmen der Psychotherapeutischen Studentenberatung am Hochschulstandort Magdeburg. 2011. https://www.ovgu.de/unimagdeburg_media/Organisation/Beauftragte/Betriebliches+Gesundheitsmanagement/Angebote/Veranstaltungsreihe+Gesundep-47642.pdf.

24. Ackermann E, Haase J, Gadisa S. Annual report 2017: Psychosocial student counselling at the university location Magdeburg. 2019.

25. Thielmann B, Ackermann E, Frommer J, Böckelmann I. Evaluation of a stress management course for students. Prävention Gesundheitsförderung. 2010;5:282-8. doi:10.1007/s11553-010-0230-9.

26. $10.1007 / \mathrm{s} 11553-020-00809-6$

Darius S, Bunzel K, Ciechanowicz E, Böckelmann I. Mental health during student teacher. Prävention und Gesundheitsförderung. 2020:in press. doi:10.1007/s11553-020-00809-6.

27. Ramm M, Multrus F, Bargel T, Schmidt M. Study situation and student orientation. 12. student survey at universities and universities of applied sciences. Konstanz: Bundesministerium für Bildung und Forschung; 2014.

28. Bíró É, Ádány R, Kósa K. Mental health and behaviour of students of public health and their correlation with social support: a cross-sectional study. BMC Public Health. 2011;11:871. doi:10.1186/1471-2458-11-871.

29. Zhang J, Liu Y, Sun L. Psychological strain and suicidal ideation: A comparison between Chinese and US college students. Psychiatry Res. 2017;255:25662. doi:10.1016/j.psychres.2017.05.046.

30. Weber J, Skodda S, Muth T, Angerer P, Loerbroks A. Stressors and resources related to academic studies and improvements suggested by medical students: a qualitative study. BMC Med Educ. 2019;19:312. doi:10.1186/s12909-019-1747-z.

31. Toscos T, Carpenter M, Drouin M, Roebuck A, Kerrigan C, Mirro M. College Students' Experiences with, and Willingness to Use, Different Types of Telemental Health Resources: Do Gender, Depression/Anxiety, or Stress Levels Matter? Telemed J E Health. 2018;24:998-1005.

doi:10.1089/tmj.2017.0243.

Page 9/10 
Figures

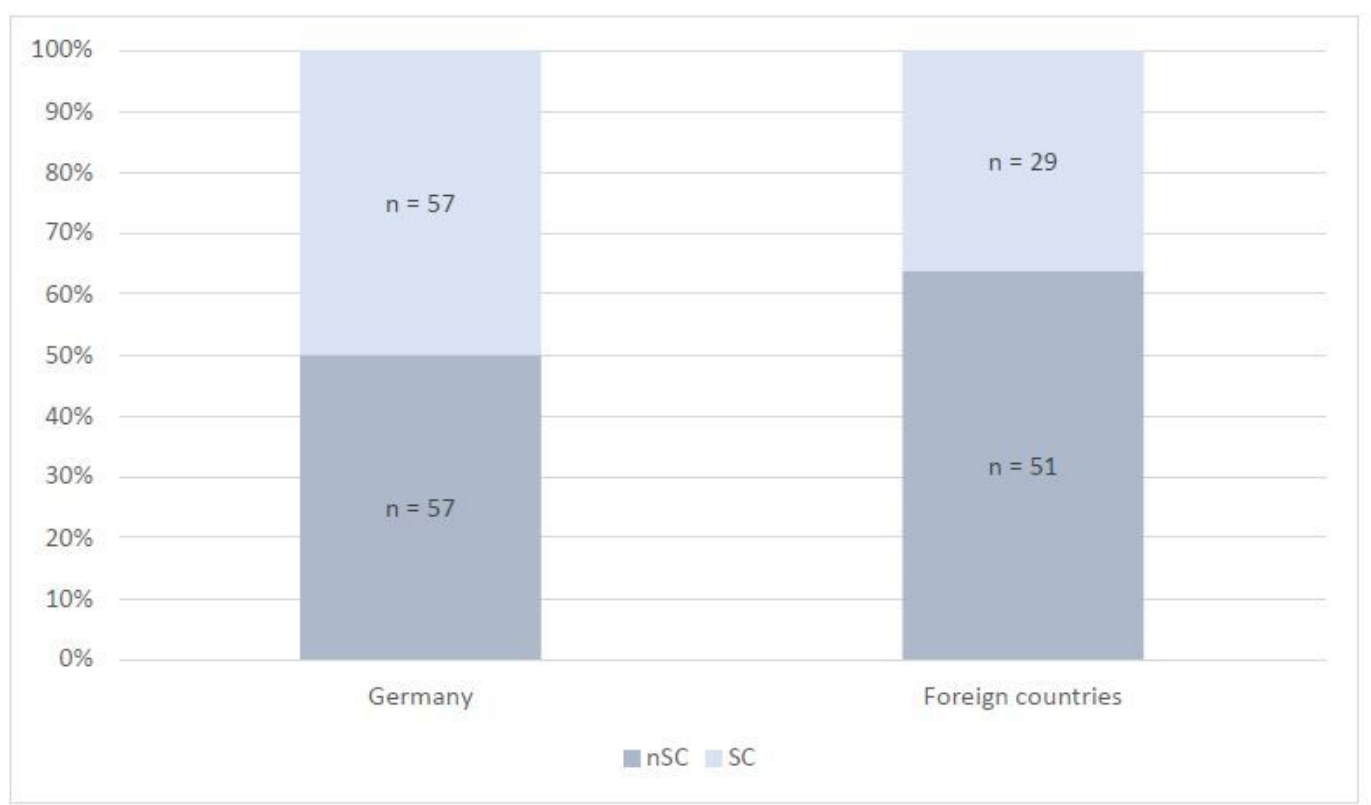

\section{Figure 1}

Allocation of subgroups with different stressful conditions among groups of students of different origins $(p=0.058)$

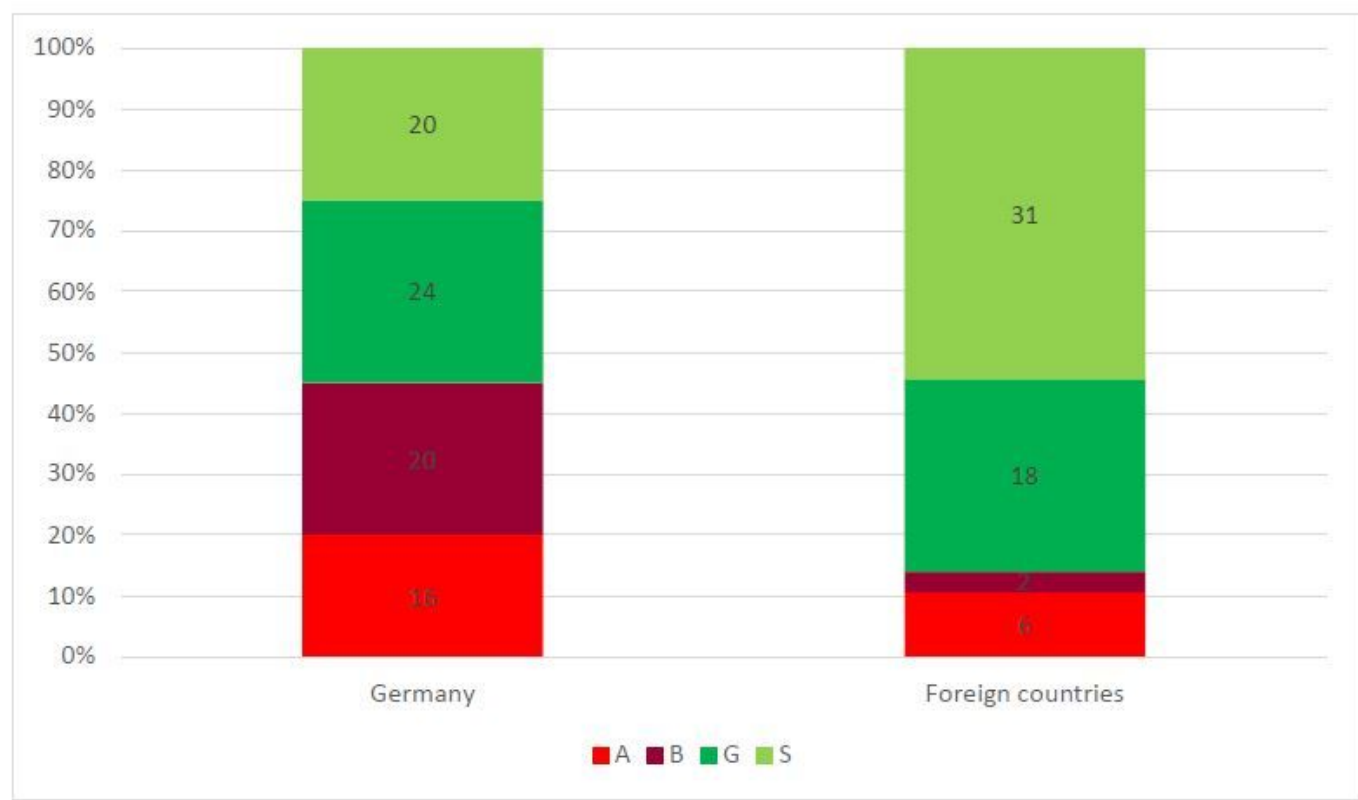

\section{Figure 2}

Allocation of subjects with different AVEM patterns in the groups of students of different origin $(p<0.001)$ 